This item was submitted to Loughborough's Research Repository by the author.

Items in Figshare are protected by copyright, with all rights reserved, unless otherwise indicated.

\title{
Media discourses of low carbon housing: the marginalisation of social and behavioural dimensions within the British broadsheet press
}

PLEASE CITE THE PUBLISHED VERSION

http://dx.doi.org/10.1177/0963662513512442

\section{PUBLISHER}

Sage / @ The Authors

VERSION

AM (Accepted Manuscript)

\section{PUBLISHER STATEMENT}

This work is made available according to the conditions of the Creative Commons Attribution-NonCommercialNoDerivatives 4.0 International (CC BY-NC-ND 4.0) licence. Full details of this licence are available at: https://creativecommons.org/licenses/by-nc-nd/4.0/

\section{LICENCE}

CC BY-NC-ND 4.0

\section{REPOSITORY RECORD}

Cherry, Catherine, Christina J. Hopfe, Brian MacGillivray, and Nick Pidgeon. 2019. "Media Discourses of Low Carbon Housing: The Marginalisation of Social and Behavioural Dimensions Within the British Broadsheet Press". figshare. https://hdl.handle.net/2134/19807. 
Media discourses of low carbon housing: the marginalisation of social and behavioural dimensions within the British broadsheet press

Cherry, C. ${ }^{\mathrm{ab}}$, Hopfe, C. ${ }^{\mathrm{b}}$, MacGillivray, B. ${ }^{\mathrm{c}} \&$ Pidgeon, N. ${ }^{\mathrm{a}}$

${ }^{a}$ School of Psychology, Cardiff University

${ }^{\mathrm{b}}$ School of Engineering, Cardiff University

c The Sustainable Places Research Institute, Cardiff University

\begin{abstract}
Decarbonising housing is a key UK Government policy to mitigate climate change. Using discourse analysis, we assess how low carbon housing is portrayed within British broadsheet media. Three distinct storylines were identified. Dominating the discourse, Zero carbon housing promotes new-build, low carbon houses as offering high technology solutions to the climate problem. Retrofitting homes emphasises the need to reduce emissions within existing housing, tackling both climate change and rising fuel prices. A more marginal discourse, Sustainable living, frames low carbon houses as related to individual identities and "off-grid" or greener lifestyles. Our analysis demonstrates that technical and economic paradigms dominate media discourse on low carbon housing, marginalising social and behavioural aspects.
\end{abstract}




\section{Low carbon housing: the policy context}

Under The Climate Change Act 2008, the UK Government is committed to an $80 \%$ reduction in greenhouse gas emissions by 2050. With British households accounting for approximately $25 \%$ of national carbon emissions (Climate Change Committee, 2010), decarbonising the domestic sector is central to achieving this target.

In 2006, the UK Government announced that all new homes must be zero carbon by 2016. Originally, the Code for Sustainable Homes (CSH) defined a zero carbon home (Code Level 6) as one where "net carbon emissions from all energy used in the dwelling are zero or better" (DCLG, 2006). Recently, debate surrounding this definition has become particularly contested. Following the formation of the UK Green Building Council (UKGBC) in 2007, and later the Zero Carbon Hub, a new consultation was conducted to assess the practicalities and challenges of implementing the original definition and decarbonising the housing stock more broadly (see McLeod et al., 2012).

Recently, the role of lifestyles, norms and social practices in shaping domestic emissions has become increasingly clear (Spence \& Pidgeon, 2009; Cabinet Office, 2011; Hargreaves, 2011). This focus on the socio-cultural dimensions of everyday living suggests that public norms and understandings will play a critical role in transitioning towards a low carbon housing sector. One important influence on public understandings is of course the media (Carvalho \& Burgess, 2005). Despite extensive research into media discourses of climate change (see Boykoff, 2009), representations of low carbon housing have not received the same scrutiny. This paper investigates media discourses surrounding decarbonisation of the 
home within the British broadsheet press (The Guardian, The Independent, The Telegraph and The Times; 2006-2011) and how, if at all, the need for social and technical change has been represented.

\section{Discourses, the media, and the environment}

Discourses can be understood as coherent sets of ideas, concepts and categories that, through language, create shared understandings of the world (Dryzek, 2005). Two components of discourse can be identified. Discursive elements are basic components used to construct issues, objects and actors within the discourse. Gamson \& Modigliani (1989) distinguish between framing devices (influencing what is thought about an issue) and reasoning devices (justifying what should be done about an issue), which are combined within storylines. These provide a "generative sort of narrative that allows actors to draw upon various discursive categories to give meaning to specific physical or social phenomena" (Hajer, 1995: 56) and generally include aspects of problem definition, causation, responsibility and moral argument. In contrast, discursive practices are the ways in which actors and "discourse coalitions" use these elements to gain credibility and promote personal positions (ibid.).

The media is an important actor in the construction of public discourses, as an arena for debate and information provision (Bell, 1994; Weingart, Engels, \& Pansegrau, 2000), and in weaving its own cultural and political meanings around issues and events (Boykoff, 2009). Media discourses reflect a complex set of journalistic norms, rather than simply describing 
the outside world. Decisions about what constitutes news, how to portray that news, and who can speak credibly on an issue, are shaped and constrained by norms privileging novelty, dramatisation, personalisation, balance, and authority-order (Boykoff \& Boykoff, 2007)

The relationship between the media and public perceptions is complex however, and is not a passive process of information uptake by the public. Instead, dynamic interactions between competing storylines and shifting relationships between politics, society and the press, shape media discourses (Carvalho \& Burgess, 2005). Although discourses cannot determine public understandings or lead to specific behaviour changes, they do matter, influencing policy formulation and institutional designs, as well as public meanings and behaviours (Kurz, Donaghue, Rapley \& Walker, 2005).

Our research adopts a grounded theory approach and does not draw on a set theoretical framework for analysis (see Supplementary Information 1 - Research Methods). However, many conceptual analytical insights were drawn from earlier work. Notably, Dryzek (2005) describes the development of different traditions within global environmental discourses. He categorises competing storylines within four broad classes, of which Quest for sustainability (the need for environmentally friendly growth and development) and Green radicalism (the need for bottom-up change from individuals and society) are particularly relevant. Echoing this, Bäckstrand \& Lövbrand (2007) outline three meta-discourses of climate change. Green governmentality (the need for international climate change governance) and Ecological Modernisation (the ability of financial markets and technology to solve 
environmental issues) are shown to dominate the debate. Resonating with Dryzek's Green Radicalism, Civic environmentalism represents as a marginalised counter discourse, focusing on citizen and community engagement.

It was not until the late 1990s that carbon compound terms, such as low carbon, entered climate change discourse, bringing with them a focus on decarbonisation. Nerlich (2012) discusses how the term was used within different industries to promote a market based framing of a prosperous low carbon future. This trend can also be seen within the housing industry, with a discourse coalition of housing and energy policy-makers actively seeking to reframe the issue of low carbon housing and position it as a climate change mitigation strategy (Lovell, 2004). Two key storylines emerged: the Life Cycle storyline (an economic framing, emphasising rationality and cost-effectiveness) and the Smart Housing storyline (framing these homes as purely technological entities, neglecting issues of lifestyle change). Building on this, our paper presents the first analysis of media representations of low carbon housing, and the discursive practices by which they have been produced.

\section{Discourses of low carbon housing}

Three discursive storylines, Zero carbon housing, Retrofitting homes and Sustainable living, were identified. Figure 1 shows their relative prevalence, demonstrating the dominance of Zero carbon housing. Particular focus was placed on identifying: a) how low carbon housing has been represented within each storyline; b) which actors (re)produce these representations and how they achieve this; and c) changes within the storylines over time or 
differences between newspaper sources. See Supplementary Information 2 - Supporting Evidence for supporting quotes referenced within this section (e.g. ZCH1 refers to the first quote for the Zero carbon housing storyline).

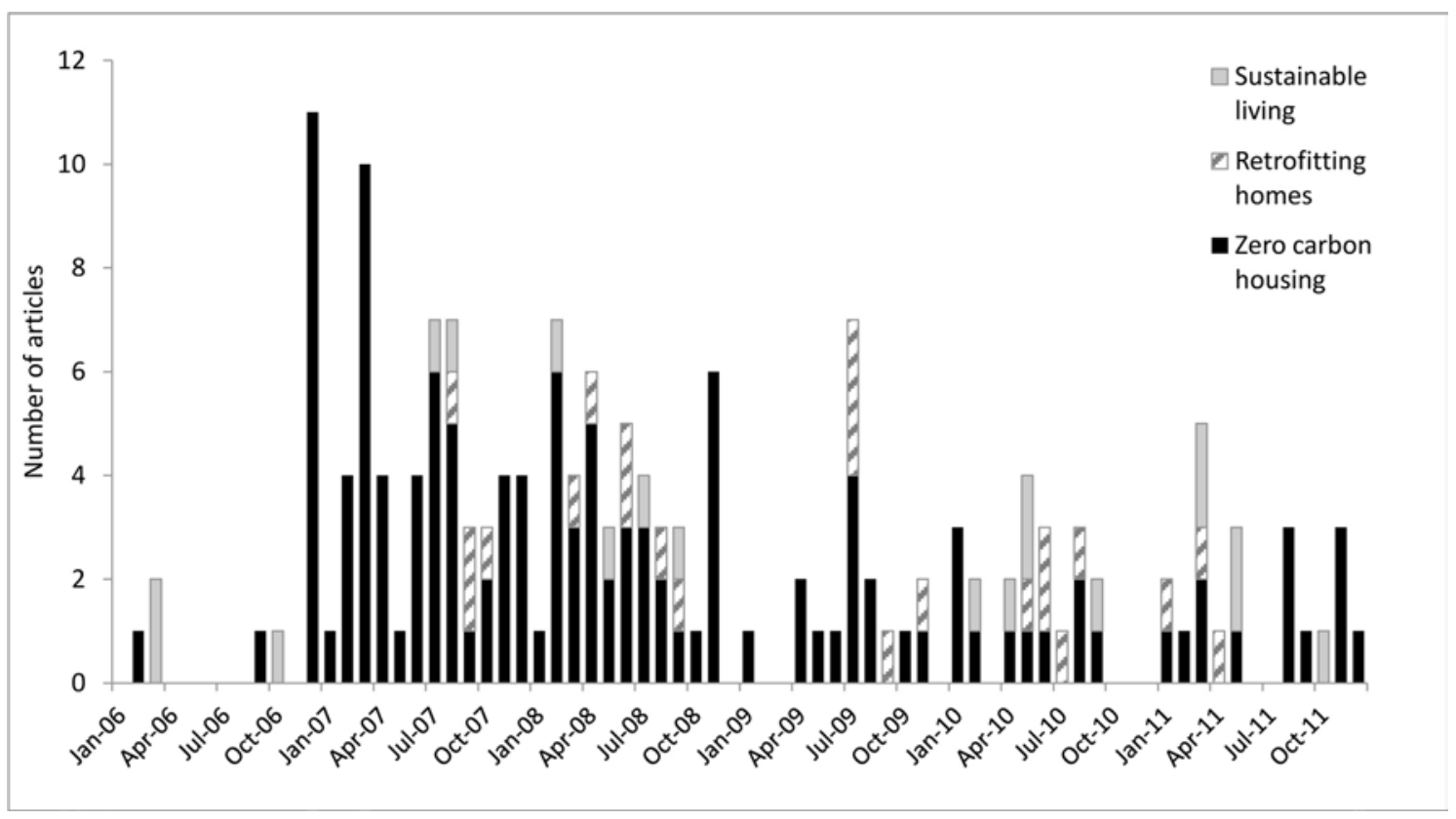

Figure 1. Number of articles appearing within each storyline (January 2006 to December 2011).

Zero carbon housing: dominating the discourse

Ministers are planning a raft of reforms to Britain's building regulations. Houses contribute nearly 30 per cent of Britain's total carbon emissions, pumping 41.7 million tons of carbon into the atmosphere each year ... millions of tons of carbon 
emissions a year could be saved by 2050 if all new homes are zero-carbon rated by 2016.

(Russell, The Independent, 07/12/2006)

Discursive elements. Zero carbon housing is primarily justified as a mechanism to meet national climate mitigation targets, with new-build housing proposed as the primary solution. The housing sector is considered a significant contributor to national carbon emissions, although little information is provided regarding specific emissions sources (e.g. heating vs. appliances). Although the urgency of reducing emissions is repeatedly emphasised, explicit mention of climate change decreases over time, with zero carbon homes increasingly positioned as a solution to rising energy bills ( $\mathrm{ZCH} 1)$.

What constitutes a zero carbon home within the storyline is vague ( $\mathrm{ZCH} 2)$. Initially considered a key feature, the prominence of onsite energy generation rapidly disappears, with attention shifting to issues of energy efficiency and building standards. Instead, a representation of the material and social characteristics of these houses is provided through descriptions and exemplar developments. Focusing on technological and design features, zero carbon houses are framed as 'cutting edge', a vision of the future ( $\mathrm{ZCH} 3)$. A competing frame (that these homes are experimental and untested) contests this, but is undermined as zero carbon houses are increasingly depicted as pioneering technology ( $\mathrm{ZCH} 4)$. 
Discursive practices. Originating within Government announcements surrounding the CSH, this storyline is reproduced within news and policy-based feature articles, rapidly gaining discursive dominance. Considering media reproductions, official quotes and several opinion pieces by prominent Government ministers, we find evidence of purposeful framing of low carbon housing as a solution to climate change. Emotional, value-laden language is combined with the idea that individual homes contribute substantially to climate change, promoting housing policy and appropriating environmental credibility (ZCH5). However, over time, the UK Government begins to downplay the contentious issue of climate change, shifting instead to a cost savings frame. With responsibility to act placed firmly with policy makers, the role of professional actors such as developers or construction firms receives little prominence. Issues surrounding behaviour change are also largely excluded. Although a range of 'alternative' positions are presented by the media, these paradoxically serve to reinforce this storyline; by focusing on criticisms of Government policy, both housing professionals and NGOs emphasise the responsibility and accountability of policy makers. A discourse coalition supports this storyline, including the UKGBC. This organisation is accredited a high level of expertise, and its formation is used to imply agreement between all actors, providing a largely unquestioned commentary in the media.

Following the UK General Election in 2010 and the formation of the Coalition Government, Zero carbon housing became increasingly contested, with the definition of zero carbon (within the $\mathrm{CSH}$ ) at the centre of debate. Through a subtle modification of the 
storyline, the UKGBC played a key role in (re)defining 'zero carbon housing', shifting focus from climate mitigation, to the practicalities of achieving change. The Coalition Government intensified this shift, purposefully excluding climate change rhetoric from discussion of the CSH. From this point, no discourse coalition is discernable and contention over the definition and achievability of zero carbon housing grows. This contention is increasingly used strategically to criticise policy and destabilise the storyline (ZCH6).

Media legitimisation of the Government position decreases following these changes to the political landscape, and ideological divisions between the newspapers become more apparent. The Guardian and The Independent are more commonly associated with strong climate change frames and more critical debate around defining zero carbon, compared to The Telegraph and The Times. However, these divisions are largely rhetorical, failing to alter the fundamental structure of the storyline.

Retrofitting homes: a counter storyline

"Nearly a quarter of the housing stock consists of solid-wall homes, many of which are period properties. Retrofitting these properties will be crucial if we are to meet our target of reducing UK emissions by at least $80 \%$ by $2050 . "$ John Alker, UK Green Building Council

(Bloomfield, The Times, 11/06/2010) 
Discursive elements. Again emphasising climate change, Retrofitting Homes is distinguished by its claim that new build, zero carbon homes fail to address the real cause of emissions: preexisting homes. Retrofitting existing housing is instead proposed, based on two arguments; 1) approximately $75 \%$ of existing homes will still be occupied in 2050 and 2) embodied emissions within construction make zero carbon housing unachievable (RH1; RH2). Stronger connections between other issues and low carbon housing are also made, particularly that of rising energy bills (RH3).

Representations of low carbon homes as cutting edge are absent, focussing instead on more pragmatic adoption of available technological options. Energy efficiency takes a central role, followed by onsite electricity generation (RH4; RH5). Although social framings primarily revolve around affordability, concepts of comfort and green living do emerge, emphasising the normality of these homes (RH6). Less commonly, ideas surrounding smart technology are also incorporated, subtly highlighting the social implications of retrofitting households (RH7).

Discursive practices. Positioned to challenge the dominance of Zero carbon housing, Retrofitting homes draws heavily on the support and opinions of alternative actors, including NGOs and academics. A combination of technical and emotional language is used to strengthen core arguments and highlight both the rationale and procedure for achieving decarbonisation. Expertise is drawn from diverse sources, including the technical knowledge and advice of 
organisations (e.g. the Royal Institute of Chartered Surveyors) and prominent individuals (RH8).

Despite the greater focus on individual residents, explicit moral reasoning (e.g. Butler, 2010) or calls for action are rare, with emphasis instead on supporting expertise and evidence. Behaviour change is rarely openly advocated and though the public are encouraged to decarbonise their homes, this is always framed as personally beneficial, rather than a moral responsibility. Engaging relatively late with this storyline, the Government appropriate it, positioning themselves as leaders and asserting that a 'revolution' in housing is needed (although limited suggestions for achieving this are provided). Given the diverse and technical nature of the debate, some contentions arise, particularly surrounding the effectiveness of micro-generation technologies and estimates of payback times. Despite this, the storyline provides a strong, generally unified criticism of Government decarbonisation policy.

Sustainable living: an alternative discourse

The three-bedroom home designed by Michael and Dorothy Rea, near the shoreline of a secluded bay, has become a test bed for living "off-grid": generating all their power from renewable sources, growing most of their food at home, and running a car without a petrol station

(Carrell, The Guardian, 19/05/2008) 
Discursive elements. Sustainable living frames sustainable housing as a solution to several issues. While reducing individual carbon footprints remains an important element, sustainable housing is portrayed as more than this, with the resource intensive nature of modern life a central issue. Sustainable self-building in particular is framed as a solution to problems such as the increasing pace of modern life (and accompanying stress and health problems), which is repeatedly highlighted as a driver for adopting sustainable lifestyles (SL1). Additionally, sustainable housing is framed as an escape from the burden of expensive fuel bills.

Again, no concrete definition is provided as to what constitutes a 'sustainable' home and little detail is given regarding their technical and material features. Cutting edge frames are absent, with focus instead placed on comfort and homeliness. The green values of residents are a prominent theme, making a link between self-building and identity. Additionally, the importance of self-sufficiency and being 'off-grid' was often critical, focusing on escaping from the power of large energy companies (SL2). A personal desire for independence, whether from the state or energy companies, and a professed sense of self-worth, is portrayed as driving residents' choices. At times an idyllic vision of low carbon housing is presented, focusing on eco-home ownership as a pathway to healthier, happier and greener living. 
Discursive practices. Representing a relatively minor strand of the overall discourse, Sustainable living pre-dates Zero carbon housing and takes shape via different discursive practices. Generally appearing independently of policy announcements, this storyline appears primarily within feature articles, utilising personal narratives to appeal to public interest in unusual lifestyles. Paradoxically, normality is also a key frame in considering these lifestyles. Self-builders and residents typically present their homes as 'normal,' often highlighting their distinctive features, but always focusing on ideas of homeliness and comfort (SL3). Media representations reinforce this, normalising significant lifestyle changes through the detached language used to describe them (SL4).

Even dramatic lifestyle changes are depicted as relatively smooth transitions into new routines, with residents portrayed as taking changes in their stride (SL5). These lifestyle choices are portrayed as personal and bound up with individual identities, rather than being framed as normative guidance for society. Moral arguments are again absent. With barely any mention of Government, residents of sustainable houses (specifically self-builders) are the central actors, reducing contention within the storyline and limiting any critique of building and design choices.

\section{Discussion}

Zero carbon housing can be situated within Quest for sustainability (Dryzek, 2005) and Ecological Modernisation (Bäckstrand \& Lövbrand, 2007) discourses, and supports Lovell's (2004) finding that low carbon housing has been purposely reframed as a solution to 
climate change. With similar foundations in Ecological modernisation, Retrofitting homes in many ways echoes that of Zero carbon housing and despite contesting the dominant storyline, remains rooted within the same techno-economic paradigm.

In contrast, Sustainable living provides a different narrative, emphasising individuality and self-sufficiency, and focussing on people living outside dominant social norms. Nevertheless, whilst echoing Dryzek's (2005) Green radicalism discourse, Sustainable living does not promote these lifestyle choices, instead portraying them as deeply individual acts expressing personal identities. A tension runs through this storyline, with significant lifestyle changes typically portrayed as undisruptive to households and framed instead as easily translated into new routines.

The normality of low carbon housing emerges as a central theme of each storyline. Despite very different discursive practices, each storyline presents low carbon living as broadly desirable, with little contestation of the need for home decarbonisation. Zero carbon housing adopts a persuasive narrative of cutting edge homes as the solution to climate change, naturalising a belief that these houses themselves, rather than occupant behaviour, will reduce emissions. Adopting more technical language, Retrofitting homes instead reflects a common sense narrative, promoting retrofitting housing as an achievable, sensible option for reducing household emissions and fuel bills. Normality is portrayed very differently within Sustainable living, with unusual lifestyles portrayed as a small sacrifice, made in exchange for increased personal comfort and happiness. Focusing on low utility bills, these 
homes are promoted as affordable, with less emphasis given to costs of purchase or construction.

Supported by a strong discourse coalition, Zero carbon housing rapidly achieved discursive dominance following the announcement of the CSH, endorsing Lovell's analysis (2004). Retrofitting homes is supported by a more disparate group of actors, becoming more prominent in 2008/9, plausibly as a result of the economic downturn and the subsequent election of the Conservative-Liberal coalition. In addition, the importance of climate change is increasingly played down, especially following the 2010 UK General elections, which may be in part due to the growing politicisation of climate change (see Pidgeon, 2012). The underlying presence of Sustainable living demonstrates that remnants of an older sustainable housing discourse still persist, despite lacking clear advocacy (such as that highlighted within Lovell, 2004).

Several common assumptions run throughout each storyline. In particular, a number of important concepts are largely absent from the media discourse. Despite the technical paradigm that dominates the discourse, certain concepts that challenge these storylines are excluded, in particular the importance of embodied emissions and difficulties surrounding achievability of modelled emissions reductions (see Monahan \& Powell, 2011a, b).

Other concepts largely excluded from the discourse include individual behaviour change, cultural expectations and social norms. Although there is continuing debate surrounding the adoption of particular theoretical frameworks, there is nevertheless broad agreement that substantial reductions in domestic emissions will require fundamental shifts 
in these aspects, perhaps leading to considerable social upheaval (Davies \& Oreszczyn, 2012; Shove, 2010; Whitmarsh, O’Neill \& Lorenzoni, 2011). While Sustainable living clearly depicts changes in behaviour and social practices within low carbon homes, these practices are nevertheless normalised, and not explicitly advocated.

The absence of these social aspects is strange as one might expect media norms, such as personalisation, to highlight them. We suggest these omissions stem from the implicit assumptions and blind spots to behaviour change currently found within the dominant technological paradigm of broader decarbonisation strategies (Spence \& Pidgeon, 2009). Whatever the reason, our analysis demonstrates that the concept of ecological modernisation is uncritically embedded within dominant media depictions of low carbon housing. Focus is placed on technical progress and economic incentives as the inevitable route to sustainability, alongside a relative neglect of the cultural and social implications of this.

Ultimately, this rather incomplete media depiction of decarbonising housing may have consequences for transitioning towards low carbon living. Despite their dynamic nature, discourses place boundaries on both the understandings and politics of phenomena, potentially excluding innovative ideas and solutions to the problem of low carbon housing. Moreover, there is the possibility that framing low carbon housing as distinctly 'normal', and as essentially imposing no restrictions or challenges to current lifestyles, institutions, and practices, may lead to social resistance when the realities of radical decarbonisation hit home. 


\section{References}

Bäckstrand, K. \& Lövbrand, E. (2007). Climate Governance Beyond 2012: Competing Discourses of Green Governmentality, Ecological Modernization and Civic Environmentalism. In Pettenger, M. (Ed.), The Social Construction of Climate Change: Power, Knowledge, Norms, Discourses (pp. 123-148). Aldershot, UK: Ashgate Publishing.

Bell, A. (1994). Media (mis)communication on the science of climate change. Public Understanding of Science, 3(3), 259-275. doi:10.1088/0963-6625/3/3/002

Boykoff, M. T., \& Boykoff, J. M. (2007). Climate change and journalistic norms: A casestudy of US mass-media coverage. Geoforum, 38(6), 1190-1204. doi:10.1016/j.geoforum.2007.01.008

Boykoff, M.T. (2009). We Speak for the Trees: Media Reporting on the Environment. The Annual Review of Environment and Resources, 34, 431-357.

Burgess, J. (1990). The Production and Consumption of Environmental Meanings in the Mass Media: A Research Agenda for the 1990s. Transactions of the Institute of British Geographers, 15(2), 139. doi:10.2307/622861

Butler, C. (2010) Morality and climate change: is leaving your T.V. on standby a risky behaviour? Environmental V alues, 19(2): 169-192.

Cabinet Office: Behavioural Insights Team (2011). Behaviour Change and Energy Use. London: Crown. Retrieved from http://www.cabinetoffice.gov.uk/resourcelibrary/behaviour-change-and-energy-use. 
Carvalho, A., \& Burgess, J. (2005). Cultural Circuits of Climate Change in U.K. Broadsheet Newspapers, 1985-2003. Risk Analysis, 25(6), 1457-1469. doi:10.1111/j.15396924.2005.00692.x

Climate Change Committee, (2010). Fourth Carbon Budget. London: Climate Change Committee. Retrieved from http://www.theccc.org.uk/reports/fourth-carbonbudget.

Davies, M., \& Oreszczyn, T. (2012). The unintended consequences of decarbonising the built environment: A UK case study. Energy and Buildings, 46, 80-85. doi:10.1016/j.enbuild.2011.10.043

DCLG. (2006) Code for Sustainable Homes: A step-change in sustainable home building practice. Department of Communities and Local Government, London. Retrieved from www.communities.gov.uk.

Dryzek, J. S. (2005). The Politics of the Earth: Environmental Discourses (2nd ed.). Oxford University Press, USA.

Gamson, W.A. \& Modigliani, A. (1989). Media Discourse and Public Opinion on Nuclear Power: A Constructionist Approach. American Journal of Sociology, 95(1), 1-37.

Hajer, M. A. (1995). The Politics of Environmental Discourse: Ecological Modernization and the Policy Process. Clarendon Press.

Hargreaves, T. (2011). Practice-ing behaviour change: Applying social practice theory to pro-environmental behaviour change. Journal of Consumer Culture, 11(1), 79-99. 
Kurz, T., Donaghue, N., Rapley, M., \& Walker, I. (2005). The ways that people talk about natural resources: discursive strategies as barriers to environmentally sustainable practices. The British Journal of Social Psychology / the British Psychological Society, 44(Pt 4), 603-620. doi:10.1348/014466604X18064

Lovell, H. (2004). Framing sustainable housing as a solution to climate change. Journal of Environmental Policy \& Planning, 6(1), 35-55. doi:10.1080/1523908042000259677

McLeod, R., Hopfe, C.J. \& Rezgui, Y. (2012). An investigation into recent proposals for a revised definition of Zero Carbon homes in the UK. Energy Policy, 46, 25-35.

Monahan, J., \& Powell, J. C. (2011a). An embodied carbon and energy analysis of modern methods of construction in housing: A case study using a lifecycle assessment framework. Energy and Buildings, 43(1), 179-188. doi:10.1016/j.enbuild.2010.09.005

Monahan, J., \& Powell, J. C. (2011b). A comparison of the energy and carbon implications of new systems of energy provision in new build housing in the UK. Energy Policy, 39(1), 290-298. doi:10.1016/j.enpol.2010.09.041

Nerlich, B, (2012). 'Low Carbon' Metals, Markets And Metaphors: The Creation Of Economic Expectations About Climate Change Mitigation, Climatic Change. 110(1-2), $31-51$

Pidgeon, N. (2012). Public understanding of, and attitudes to, climate change: UK and international perspectives and policy. Climate Policy, 12, S85-S106.

Shove, E. (2010). Beyond the ABC: climate change policy and theories of social change. Environment and Planning A, 42(6), 1273-1285. doi:10.1068/a42282 
Spence, A. \& Pidgeon, N.F. (2009) Psychology, climate change and sustainable behaviour, Environment: Science and Policy for Sustainable Development, 51(6), 8-18.

Weingart, P., Engels, A., \& Pansegrau, P. (2000). Risks of communication: discourses on climate change in science, politics, and the mass media. Public Understanding of Science, 9(3), 261-283. doi:10.1088/0963-6625/9/3/304

Whitmarsh, L., O'Neill, S. \& Lorenzoni, I. (2011). Climate change or social change? Debate within, amongst and beyond disciplines. Environment and Planning A, 43, 258-261. doi:10.1068/a43359 